\title{
Pengaruh Persepsi Siswa atas Gaya Hidup Digital dan Minat Belajar terhadap Kemampuan Menulis Teks Deskripsi
}

\author{
Fini Fitriani ${ }^{1)}$ \\ Universitas Indraprasta PGRI \\ Jalan Nangka No. 58 C/TB. Simatupang, Tanjung Barat, Jakarta Selatan 12530 \\ Bambang Sumadyo ${ }^{2)}$ \\ Universitas Indraprasta PGRI \\ Jalan Nangka No. 58 C/TB. Simatupang, Tanjung Barat, Jakarta Selatan 12530 \\ Restoeningrum $^{3)}$ \\ Universitas Indraprasta PGRI \\ Jalan Nangka No. 58 C/TB. Simatupang, Tanjung Barat, Jakarta Selatan 12530 \\ finigreeny11@gmail.com ${ }^{1)}$
}

\begin{abstract}
The purpose of this study was to determine: (1) The effect of students' perceptions of digital lifestyle and interest in learning together on the ability to write descriptions of state junior high school students in Lebak Regency. (2) The effect of students' perceptions of digital lifestyle on the ability to write descriptions of state junior high school students in Lebak Regency. (3) The effect of interest in learning on the ability to write descriptions of state junior high school students in Lebak Regency. The method used in this study is a survey method. The sample used in this study were 100 students of class VII State Junior High School in Lebak Regency. The results showed: (1) There was a significant influence of students' perceptions of digital lifestyle and interest in learning together on the ability to write descriptions of students of state junior high schools in Lebak Regency. This is evidenced by the acquisition of Sig. 0,000 $<0.05$ and Fh =13,868(2) There is a significant influence of students' perceptions of digital lifestyle on the ability to write description of state junior high school students in Lebak Regency. This is evidenced by the acquisition of Sig. $0.006<0.05$ and th = 2.798. (3) There is a significant influence of interest in learning on the ability to write descriptions of state junior high school students in Lebak Regency. This is evidenced by the acquisition of Sig. $0,000<0.05$ and th $=3,720$
\end{abstract}

Keywords: Perception of Digital Lifestyle, Interest in Learning, Ability to Write Descriptions

\begin{abstract}
Abstrak
Tujuan penelitian ini untuk mengetahui: (1) Pengaruh persepsi siswa atas gaya hidup digital dan minat belajar secara bersama-sama terhadap kemampuan menulis deskripsi siswa SMP Negeri di Kabupaten Lebak. (2) Pengaruh persepsi siswa atas gaya hidup digital terhadap kemampuan menulis deskripsi siswa SMP Negeri di Kabupaten Lebak. (3) Pengaruh minat belajar terhadap kemampuan menulis deskripsi siswa SMP Negeri di Kabupaten Lebak. Metode yang digunakan dalam penelitian ini adalah metode survei. Sampel yang digunakan dalam penelitian ini sebanyak 100 siswa kelas VII SMP Negeri di Kabupaten Lebak. Hasil penelitian menunjukkan: (1) Terdapat pengaruh yang signifikan persepsi siswa atas gaya hidup digital dan minat belajar secara bersama-sama terhadap kemampuan menulis deskripsi siswa SMP Negeri di Kabupaten Lebak. Hal ini dibuktikan dengan perolehan nilai Sig. $0,000<0,05$ dan $F_{h}=13,868$ (2) Terdapat pengaruh yang signifikan persepsi siswa atas gaya hidup digital terhadap kemampuan menulis deskripsi siswa SMP Negeri di Kabupaten Lebak. Hal ini dibuktikan dengan perolehan nilai Sig. 0,006 <0,05 dan $t_{h}=2,798$. (3) Terdapat pengaruh yang signifikan minat belajar terhadap kemampuan menulis deskripsi siswa SMP
\end{abstract}

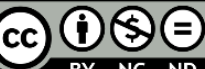

Creative Commons Attribution-NonCommercial-NoDerivatives 4.0 International License 
Negeri di Kabupaten Lebak. Hal ini dibuktikan dengan perolehan nilai Sig. $0,000<0,05$ dan $t_{h}=$ 3,720 .

Kata Kunci: Persepsi Gaya Hidup Digital, Minat Belajar, Kemampuan Menulis Deskripsi

\section{PENDAHULUAN}

Mata pelajaran Bahasa Indonesia merupakan mata pelajaran yang diajarkan di sekolah sejak sekolah dasar sampai perguruan tinggi. Mata pelajaran ini dianggap penting untuk diajarkan di sekolah. BSNP (2006) menjelaskan bahwa bahasa memiliki peran sentral dalam perkembangan intelektual, sosial, dan emosional peserta didik dan merupakan penunjang keberhasilan dalam mempelajari semua bidang studi. Adapun ruang lingkup mata pelajaran Bahasa Indonesia mencakup komponen kemampuan berbahasa dan kemampuan bersastra yang meliputi aspekaspek: (1) mendengarkan, (2) berbicara, (3) membaca, dan (4) menulis (BSNP, 2006a; 2006b; 2006c).

Kompetensi menulis dalam pengajaran berbahasa dan bersastra adalah tataran yang tersulit dibandingkan tiga kompetensi lainnya, yaitu mendengarkan, membaca, dan berbicara. Hal ini dikarenakan kompetensi menulis memerlukan keterampilan berpikir logis dan bernalar.

Kemampuan menulis setiap siswa tidak dapat diperoleh secara alamiah atau diwarisi dari leluhurnya, namun setiap siswa perlu dilatih dan mempelajari secara sungguh-sungguh sejak dini sebagai bekal pendidikan lanjutan. Dengan demikian, aktivitas menulis menjadi suatu keterampilan berbahasa yang membutuhkan perhatian sungguh-sungguh.

Keberhasilan seorang guru membimbing siswa sehingga mampu menulis yang baik dapat dijadikan tolok ukur keberhasilan dalam mengajar kebahasaan dan kesastraan. Bagi siswa, kemampuan menulis yang baik dapat menjadi tolok ukur keberhasilan belajar karena dirinya dapat menjadi manusia yang terampil, produktif, sekaligus pemantik menjadi manusia yang berilmu dan berwawasan luas.

Namun, adakalanya beberapa kendala dapat mempengaruhi ketidakberhasilan pengajaran menulis di tingkat SMP. Di antaranya adalah faktor tenaga pengajar, pelajar (siswa), sarana pembelajaran, dan sistem pembelajaran, serta serbuan kehadiran gadget.

Dikaitkan dengan tenaga pengajar, kenyataan di lapangan masih jarang pengajar bidang kebahasaan dan kesastraan yang berprofesi juga sebagai seorang pengarang (penulis produktif). Padahal pengajar yang mempunyai kemampuan mencipta puisi, cerita pendek, novel, dan karangan deskripsi bisa jadi cara mengajarnya akan lebih baik, akan lebih menarik minat siswa belajar dibandingkan seorang pengajar yang hanya mengajarkan teori menulis.

Ditinjau dari kendala yang berasal dari faktor siswa, antara lain minat belajar menulis siswa masih sangat rendah, minat membaca dan penguasaan kosakata yang dimiliki siswa juga relatif rendah, sehingga pembelajaran menulis hasilnya tidak maksimal. Minat membaca sangat diperlukan untuk mengembangkan pengetahuan dan wawasan siswa, demikian juga penguasaan kosakata dan penguasaan kalimat sangat diperlukan untuk dapat menghasilkan tulisan yang baik 
Faktor lain yang turut menyumbang ketidakberhasilan pengajaran menulis adalah sistem pendidikan yang belum mengakomodasi model pembelajaran menulis yang tepat guna. Termasuk faktor sarana pembelajaran, terlihat masih minimnya sumber belajar menulis dan media pembelajaran yang mendukung pembelajaran menulis.

Faktor terakhir yang cukup mengkhawatirkan berbagai kalangan di dunia pendidikan dan orang tua siswa, yang terang-terangan mengancam kemampuan siswa menulis deskripsi adalah serbuan gadget yang berdaya tarik tinggi. Baik secara langsung maupun tidak langsung kehadiran gadget zaman sekarang banyak menyita waktu pelajar untuk menggunakannya, dan celakanya, hal itu berimbas kepada kemampuan menulis pelajar. Jadi permasalahan utama para siswa adalah kurangnya kemampuan menulis. Sebagian besar siswa mengalami kesulitan menulis dalam karangan esai, termasuk di sini kemampuan menulis deskripsi. Oleh karena itu, masalah kemampuan menulis siswa cukup menarik untuk diteliti lebih lanjut, terutama dalam kaitannya dengan minat belajar dan persepsi siswa terhadap gaya hidup digital.

Berdasarkan uraian di atas maka untuk membuktikan dugaan tersebut penulis tertarik untuk melakukan penelitian dengan harapan dapat diperoleh data dan informasi secara empirik mengenai hubungan persepsi siswa atas gaya hidup digital dan minat belajar dengan kemampuan menulis deskripsi siswa, maka untuk kepentingan penelitian yang dimaksud, penulis awali dengan merumuskan sebuah judul penelitian yaitu: "Pengaruh Persepsi Siswa Atas Gaya Hidup Digital dan Minat Belajar Terhadap Kemampuan Menulis Deskripsi (Survei pada SMP Negeri di Kabupaten Lebak)".

\section{METODE}

Penelitian dilakukan pada siswa kelas VII SMP Negeri di Kabupaten Lebak yang melibatkan 3 (tiga) sekolah yaitu SMP Negeri 3 Rangkasbitung, SMP Negeri 6 Rangkasbitung, SMP Negeri 9 Rangkasbitung pertengahan semester genap tahun akademik 2019/2020. Penelitian ini berlangsung selama 4 bulan, yaitu dari bulan Maret sampai Juni 2020. Metode dalam penelitian ini adalah survei dengan menggunakan teknik analisis korelasional dan regresi.

Desain penelitiannya dapat digambarkan sebagai berikut:

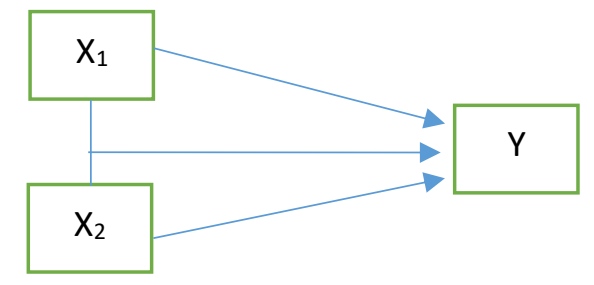

\section{Gambar 1. Desain Penelitian}

Keterangan:

$\mathrm{X}_{1}$ : Persepsi siswa atas gaya hidup digital

$\mathrm{X}_{2}$ : Minat belajar

Y: Kemampuan menulis deskripsi 
Teknik sampling yang digunakan dalam penelitian ini adalah dengan menggunakan probability sampling dengan teknik simple random sampling. Dengan teknik ini diperoleh sampel sebanyak 83 siswa.

\section{HASIL PENELITIAN}

\section{Landasan Teori}

Adapun teori dalam penelitian ini akan dipaparkan sebagai berikut. Sugihartono, dkk. (2007:8) mengemukakan bahwa persepsi adalah kemampuan otak dalam menerjemahkan stimulus atau proses untuk menerjemahkan stimulus yang masuk ke dalam alat indera manusia. Persepsi manusia terdapat perbedaan sudut pandang dalam penginderaan. Ada yang mempersepsikan sesuatu itu baik atau persepsi yang positif maupun persepsi negatif yang akan mempengaruhi tindakan manusia yang tampak atau nyata, sedangkan Adisaputro (2014:81) mengemukakan bahwa gaya hidup merupakan pola hidup seseorang yang diekspresikan terhadap aktivitas, perhatian, dan pendapat-pendapatnya. Sementara itu, Tom E Rolnicki (2008:410) mengungkapkan bahwa digital adalah kata, gambar, dan grafis yang mendeskripsikan dalam bentuk numeris melalui peranti komputer. Bila berbicara digital maka perlu diketahui tentang rangkaian dan sistem digital karena dalam kehidupan sehari-hari sistem digital inilah yang dibenamkan dalam peralatan elektronik seperti personal computer $(P C)$, handphone, dan lainlain. Jadi, persepsi siswa atas gaya hidup digital adalah pandangan siswa terhadap perilaku atau kebiasaan siswa dalam menggunakan perangkat digital, terutama untuk digunakan dalam pembelajaran menulis deskripsi.

Slameto (2018:180) mengungkapkan bahwa minat adalah suatu rasa lebih suka dan rasa ketertarikan pada suatu hal atau aktivitas tanpa ada yang menyuruh. Minat pada dasarnya adalah penerimaan akan suatu hubungan antara diri sendiri dengan sesuatu di luar diri. Semakin kuat atau dekat suatu hubungan tersebut, semakin besar minat, sedangkan, Wittig (dalam Syah, 2003 : 65-66) mengungkapkan belajar sebagai any relatively permanen change in an organism behavioral repertoire that accurs as a result of experience (belajar adalah perubahan yang relatif menetap yang terjadi dalam segala macam/keseluruhan tingkah laku suatu organisme sebagai hasil pengalaman). Jadi, minat belajar adalah kecenderungan individu untuk memiliki rasa senang tanpa ada paksaan sehingga dapat menyebabkan perubahan pengetahuan, keterampilan, dan tingkah laku.

Soehardi (2003:24) mengungkapkan bahwa kemampuan (abilities) adalah bakat yang melekat pada seseorang untuk melakukan suatu kegiatan secara fisik atau mental yang ia peroleh sejak lahir, belajar, dan dari pengalaman. Sementara itu, Suhendar (2002:56) menyatakan bahwa menulis merupakan proses bentuk pikiran, angan-angan, dan perasaan untuk menjadi wujud lambang, tanda, atau tulisan. Lebih lanjut dikatakan bahwa menulis merupakan kegiatan pengungkapan gagasan yang tertulis yang berbeda dengan kegiatan pengungkapan gagasan secara lisan, sedangkan Semi (2007:66) mengungkapkan bahwa deskripsi ialah tulisan yang tujuannya untuk memberikan rincian atau detail tentang objek sehingga dapat memberi pengaruh pada emosi dan menciptakan imajinasi pembaca bagaikan melihat, mendengar, atau merasakan langsung apa yang disampaikan penulis. Jadi, 
kemampuan menulis deskripsi adalah kemampuan untuk membuat tulisan atau wacana yang berbentuk paparan untuk menerangkan, menjelaskan, dan menguraikan suatu objek dengan tujuan utama memberitahukan atau memberikan informasi mengenai objek tersebut sehingga dapat memperluas wawasan dan pengetahuan pembaca.

Berikut ini akan diuraikan hasil penelitian tentang pengaruh persepsi siswa atas gaya hidup digital dan minat belajar terhadap kemampuan menulis deskripsi.

\section{Deskripsi Data}

Dari hasil data kuesioner persepsi siswa atas gaya hidup digital dan minat belajar serta hasil nilai tes kemampuan menulis deskripsi diperoleh nilai mean, median, modus dan simpangan baku seperti pada tabel berikut ini

Tabel 1. Rangkuman Hasil Perhitungan Statistik Deskriptif

\begin{tabular}{lrrr}
\hline \multicolumn{1}{c}{$\begin{array}{c}\text { Ukuran } \\
\text { Deskriptif }\end{array}$} & $\begin{array}{c}\text { Persepsi Siswa atas } \\
\text { Gaya Hidup Digital } \\
\left(\mathbf{X}_{\mathbf{1}}\right)\end{array}$ & $\begin{array}{c}\text { Minat } \\
\text { Belajar } \\
\left(\mathbf{X}_{\mathbf{2}}\right)\end{array}$ & $\begin{array}{c}\text { Kemampuan } \\
\text { Menulis Deskripsi } \\
(\mathbf{Y})\end{array}$ \\
\hline Mean & 78,45 & 97,92 & 63,23 \\
Median & 79,00 & 98,00 & 63,00 \\
Modus & 85 & 95 & 63 \\
Simpangan & 10,063 & 6,083 & 7,526 \\
Baku & & & \\
\hline
\end{tabular}

\section{Uji Persyaratan Data}

Uji persyaratan analisis data terdiri dari uji normalitas, uji multikolinearitas, uji heteroskedastisitas, uji normalitas galat, dan uji linearitas.

\section{Tabel 2. Rangkuman Hasil Uji Normalitas}

\begin{tabular}{lcl}
\hline \multicolumn{1}{c}{ Variabel } & Sig. & \multicolumn{1}{c}{ Simpulan } \\
\hline Persepsi Siswa atas Gaya Hidup Digital & 0,505 & Data Berdistribusi \\
$\left(\mathrm{X}_{1}\right)$ & 0,215 & normal \\
Minat Belajar $\left(\mathrm{X}_{2}\right)$ & 0,294 & Data Berdistribusi normal \\
Kemampuan Menulis Deskripsi $(\mathrm{Y})$ & &
\end{tabular}

Tabel 3. Rangkuman Hasil Uji Multikolinearitas

\begin{tabular}{lccc}
\hline \multicolumn{1}{c}{ Variabel } & VIF $_{\text {hitung }}$ & VIF & Keterangan \\
\hline $\begin{array}{l}\text { Persepsi Siswa atas Gaya Hidup } \\
\begin{array}{l}\text { Digital dan Minat Belajar } \\
\text { terhadap Kemampuan Menulis }\end{array}\end{array}$ & 1,053 & 10 & $\begin{array}{c}\text { Tidak terjadi masalah } \\
\text { multikolinieritas }\end{array}$ \\
Deskripsi & & & \\
\hline
\end{tabular}


Diskursus: Jurnal Pendidikan Bahasa Indonesia

Vol. 3, No. 2, Agustus 2020, pp. 139-148

p-ISSN: $2615-4935$

e-ISSN: $2615-4943$

Tabel 4. Uji Normalitas Galat

One-Sample Kolmogorov-Smirnov Test

\begin{tabular}{llr}
\hline \multicolumn{2}{c}{ One-Sample Kolmogorov-Smirnov Test } \\
\hline $\mathrm{N}$ & & $\begin{array}{c}\text { Unstandardized } \\
\text { Residual }\end{array}$ \\
Normal Parameters ${ }^{\mathrm{a}, \mathrm{b}}$ & Mean & 100 \\
& Std. Deviation & $0 \mathrm{E}-7$ \\
& Absolute & $, 0,63687273$ \\
Most Extreme Differences & Positive &, 042 \\
& Negative &,- 076 \\
Kolmogorov-Smirnov Z & &, 761 \\
Asymp. Sig. (2-tailed) & &, 609 \\
\hline
\end{tabular}

a. Test distribution is Normal.

b. Calculated from data.

Tabel 5. Rangkuman Hasil Uji Linearitas

\begin{tabular}{lcc}
\hline \multicolumn{1}{c}{ Garis Yang Diuji } & Sig. & Simpulan \\
\hline $\mathrm{X}_{1}$ terhadap Y & 0,849 & Model regresi berpola linier \\
$\mathrm{X}_{2}$ terhadap Y & 0,149 & Model regresi berpola linier \\
\hline
\end{tabular}

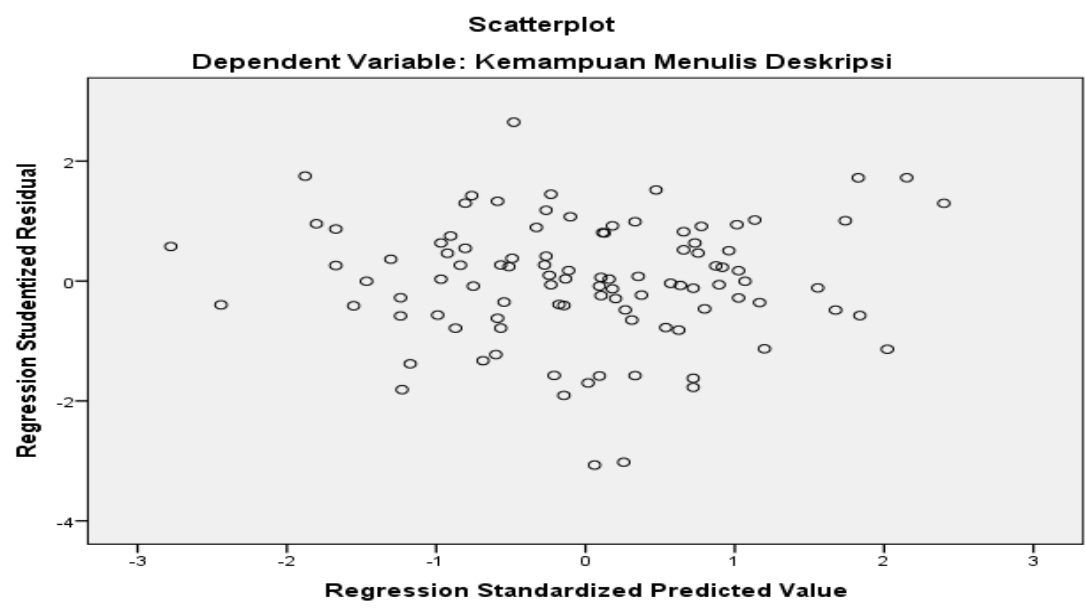

Gambar 2. Scatterplot Uji Heteroskedastisitas

Berdasarkan tabel 2 di atas, maka dapat disimpulkan bahwa data dari ketiga variabel penelitian menunjukkan semua sampel lebih besar dari 0,05 sehingga $\mathrm{H}_{0}$ diterima. Dengan kata lain data dari semua sampel penelitian terdistribusi normal.

Hasil uji multikolinearitas pada tabel 3 di atas diketahui bahwa hasil Varian Inflation Factor (VIF) 1,053 < 10. Sehingga dapat dinyatakan bahwa tidak ada multikolinearitas antara persepsi siswa atas gaya hidup digital dengan minat belajar pada analisis regresi ganda ini. 
Dari tabel 4 di atas menunjukkan bahwa uji hipotesis yang menyatakan distribusi residual pada analisis regresi linear berganda ini mengikuti distribusi normal. Hal ini ditunjukkan dengan nilai $Z=0,761$ dan Sig. $=0,609>0,05$. Hal ini berarti asumsi atau persyaratan analisis regresi terpenuhi.

Berdasarkan tabel 5 di atas, maka dapat disimpulkan bahwa data dari kedua model regresi yang diuji menunjukkan memiliki nilai Sig. lebih besar dari 0,05 sehingga $\mathrm{H}_{0}$ diterima. Dengan kata lain data dari semua model regresi yang diuji berpola linier.

Dari gambar 2 di atas menunjukkan bahwa titik-titik menyebar secara acak dan tidak membentuk pola tertentu yang jelas, serta tersebar di atas maupun di bawah angka 0 pada sumbu Y. Hal ini menunjukkan bahwa tidak terjadi heteroskedastisitas pada model regresi tersebut, sehingga dapat dipakai untuk memprediksi variabel kemampuan menulis deskripsi berdasarkan persepsi siswa atas gaya hidup digital dan minat belajar.

\section{Pengujian Hipotesis}

Tabel 5. Hasil Perhitungan Pengujian Koefisien Korelasi Ganda Variabel X1 dan X2 terhadap Y

Model Summary ${ }^{b}$

\begin{tabular}{lrrrr}
\hline Model & $\mathrm{R}$ & $\mathrm{R}$ Square & Adjusted R Square & \multicolumn{2}{c}{$\begin{array}{c}\text { Std. Error of the } \\
\text { Estimate }\end{array}$} \\
\hline 1 &, $472^{\mathrm{a}}$ &, 222 &, 206 & \\
\hline
\end{tabular}

a. Predictors: (Constant), Minat Belajar, Persepsi Siswa atas Gaya Hidup Digital

b. Dependent Variable: Kemampuan Menulis Deskripsi

Tabel 6. Hasil Perhitungan Pengujian Signifikansi Koefisien Regresi Variabel $X_{1}$ dan $X_{2}$ terhadap $Y$

\begin{tabular}{|c|c|c|c|c|c|}
\hline \multicolumn{6}{|c|}{ ANOVA $^{a}$} \\
\hline Model & Sum of Squares & df & Mean Square & $\mathrm{F}$ & Sig. \\
\hline Regression & 1246,950 & 2 & 623,475 & 13,868 &, $000^{\mathrm{b}}$ \\
\hline 1 Residual & 4360,760 & 97 & 44,956 & & \\
\hline Total & 5607,710 & 99 & & & \\
\hline
\end{tabular}

a. Dependent Variable: Kemampuan Menulis Deskripsi

b. Predictors: (Constant), Minat Belajar, Persepsi Siswa atas Gaya Hidup Digital

Tabel 7. Hasil Perhitungan Persamaan Regresi Ganda Variabel $X_{1}$ dan $X_{2}$ terhadap $Y$

\section{Coefficients $^{\text {a }}$}

Model

\begin{tabular}{|c|c|c|c|c|}
\hline \multicolumn{2}{|c|}{$\begin{array}{c}\text { Unstandardized } \\
\text { Coefficients }\end{array}$} & $\begin{array}{l}\text { Standardized } \\
\text { Coefficients }\end{array}$ & \multirow{2}{*}{$\mathrm{T}$} & \multirow{2}{*}{ Sig. } \\
\hline B & $\begin{array}{l}\text { Std. } \\
\text { Error }\end{array}$ & Beta & & \\
\hline
\end{tabular}


Diskursus: Jurnal Pendidikan Bahasa Indonesia

Vol. 3, No. 2, Agustus 2020, pp. 139-148

p-ISSN: $2615-4935$

e-ISSN: $2615-4943$

\begin{tabular}{lrrrrr} 
(Constant) & 6,737 & 11,246 & &, 599 &, 551 \\
Persepsi Siswa atas Gaya Hidup &, 192 &, 069 &, 257 & 2,798 &, 006 \\
$\begin{array}{l}\text { Digital } \\
\text { Minat Belajar }\end{array}$ &, 423 &, 114 &, 342 & 3,720 &, 000 \\
\hline
\end{tabular}

a. Dependent Variable: Kemampuan Menulis Deskripsi

Dari tabel 5 di atas dapat dilihat bahwa koefisien korelasi ganda pengaruh variabel persepsi siswa atas gaya hidup digital $\left(\mathrm{X}_{1}\right)$ dan minat belajar $\left(\mathrm{X}_{2}\right)$ secara bersama-sama terhadap kemampuan menulis deskripsi (Y) adalah 0,472. Sedangkan koefisien determinasinya sebesar 0,222 (22,2\%). Hal ini menunjukkan bahwa besarnya kontribusi persepsi siswa atas gaya hidup digital dan minat belajar secara bersama-sama terhadap kemampuan menulis deskripsi sebesar 22,2\%, sisanya $(77,8 \%)$ dipengaruhi oleh faktor-faktor lain. Dari tabel 7 diperoleh persamaan regresi yang menunjukkan pengaruh variabel $\mathrm{X}_{1}$ dan $\mathrm{X}_{2}$ terhadap variabel Y sebagai berikut: $\hat{Y}=6,737+0,192 X_{1}+0,423 X_{2}$.

Pengujian signifikansi regresi pertama sebagaimana terlihat pada tabel 6, menunjukkan bahwa nilai sig $=0,000<0,05$ dan $F_{\text {hitung }}=13,868>3,09\left(\mathrm{~F}_{\text {tabel }}\right.$ dengan derajat pembilang $(\mathrm{k})=2$ dan derajat penyebut $(\mathrm{n}-\mathrm{k}-1)=97)$, sehingga $\mathrm{H}_{0}$ ditolak dan $\mathrm{H}_{1}$ diterima yang berarti bahwa terdapat pengaruh signifikan variabel persepsi siswa atas gaya hidup digital $\left(\mathrm{X}_{1}\right)$ dan minat belajar $\left(\mathrm{X}_{2}\right)$ secara bersamasama terhadap kemampuan menulis deskripsi (Y).

Dari tabel 7 dapat dinyatakan bahwa terdapat pengaruh yang signifikan persepsi siswa atas gaya hidup digital terhadap kemampuan menulis deskripsi. Hal ini dibuktikan dengan perolehan nilai Sig. $0,006<0,05$ dan $t_{\text {hitung }}=2,798$. Selain itu, dari tabel 7 juga dapat diketahui bahwa terdapat pengaruh yang signifikan minat belajar terhadap kemampuan menulis deskripsi. Hal ini dibuktikan dengan perolehan nilai Sig. $0,000<0,05$ dan $t_{\text {hitung }}=3,720$.

\section{Pembahasan}

Berpedoman pada hasil analisis diketahui bahwa terdapat pengaruh yang signifikan persepsi siswa atas gaya hidup digital dan minat belajar secara bersamasama terhadap kemampuan menulis deskripsi siswa SMP Negeri di Kabupaten Lebak. Dalam proses pembelajaran banyak faktor yang mempengaruhi siswa, di antaranya adalah persepsi siswa atas gaya hidup digital. Persepsi merupakan pandangan seseorang dalam mengumpulkan informasi dan menafsirkan pesan dari sebuah pengalamannya dengan bantuan sistem indera. Sedangkan persepsi siswa atas gaya hidup digital adalah tanggapan seseorang dari hasil kinerja panca inderanya tentang pola hidup yang tidak lepas dengan penggunaan alat-alat yang menggunakan teknologi digital terutama elektronik dan khususnya handphone dan personal computer. Oleh karena itu, persepsi tentang gaya hidup digital harus dikelola seefisien dan seefektif mungkin sehingga memberikan pengaruh yang baik terhadap kemampuan menulis deskripsi.

Faktor lainnya adalah minat belajar Bahasa Indonesia. Minat merupakan suatu perangkat mental yang terdiri dari suatu campuran antara perasaan, harapan, pendirian, prasangka, rasa takut atau kecenderungan-kecenderungan lain yang mengarahkan seseorang pada suatu pilihan tertentu. Sedangkan kemampuan 
menulis deskripsi adalah hasil usaha belajar yang dicapai oleh seorang siswa berupa suatu kecakapan dari kegiatan belajar Bahasa Indonesia, serta pencapaian keterampilan dan sikap yang terkait dengan wawasan tentang Bahasa Indonesia.

Minat memiliki manfaat sebagai pendorong yang diberikan oleh pendidik. Sehingga tidak sulit bagi peserta didik dalam mengerjakan soal atau pertanyaan. Hal tersebut menghasilkan nilai yang bagus dan meningkatkan prestasi peserta didik.

Dari teori tersebut maka dapat dikatakan bahwa jika persepsi siswa atas dunia digital dan minat belajar baik, maka kemampuan menulis deskripsi siswa akan meningkat.

Dari informasi kuantitatif dan teori tersebut peneliti berkesimpulan bahwa persepsi siswa atas gaya hidup digital dan minat belajar secara bersama-sama memberikan pengaruh yang signifikan terhadap kemampuan menulis deskripsi.

Sementara itu, persepsi siswa atas gaya hidup digital telah memberikan pengaruh positif terhadap peningkatan kemampuan menulis deskripsi siswa SMP Negeri di Kabupaten Lebak. Artinya, persepsi siswa atas gaya hidup digital yang tinggi telah memberikan pengaruh yang signifikan terhadap peningkatan kemampuan menulis deskripsi siswa SMP Negeri di Kabupaten Lebak.

Menurut sintesis teori, persepsi gaya hidup digital adalah pencatatan indera, pengenalan pola, dan perhatian terhadap seseorang dalam mengelola waktu dan uangnya dalam kaitannya dengan penggunaan dan kepemilikan peralatan digital terutama handphone dan personal computer, yaitu kita memilih, mengatur, dan menerjemahkan masukan informasi untuk menciptakan gambaran dunia yang berarti tentang bagaimana seseorang menggunakan dan membagi waktunya dalam aktivitas sehari-hari dan bagaimana ia menghabiskan uangnya demi hasratnya terhadap penggunaan teknologi digital.

Persepsi terhadap gaya hidup digital seseorang dipengaruhi oleh faktor internal dan eksternal orang yang bersangkutan. Faktor internal itu meliputi: perasaan, sikap, dan kepribadian individu, prasangka, keinginan atau harapan, perhatian (fokus), proses belajar, keadaan fisik, gangguan kejiwaan, nilai dan kebutuhan juga minat dan motivasi. Sedangkan faktor eksternal meliputi: latar belakang keluarga, informasi yang diperoleh, pengetahuan dan kebutuhan sekitar, intensitas, ukuran, keberlawanan, pengulangan gerak, hal-hal baru dan familiar atau ketidakasingan suatu objek. Kondisi seseorang berbeda-beda baik keadaan yang berhubungan dengan faktor internal maupun eksternal sehingga persepsi gaya hidup digital tiap-tiap orang bisa jadi berbeda yang tentunya akan membawa dampak pada diri orang tersebut juga berbeda-beda. Ada yang berdampak positif ada juga yang berdampak negatif. Oleh karena itu, persepsi tentang gaya hidup digital harus dikelola seefisien dan seefektif mungkin sehingga memberikan pengaruh yang baik terhadap kemampuan menulis deskripsi.

Variabel yang terakhir yang berpengaruh terhadap kemampuan menulis deskripsi adalah minat belajar. Hasil penelitian di atas menyimpulkan bahwa minat belajar telah memberikan pengaruh positif terhadap peningkatan kemampuan menulis deskripsi siswa SMP Negeri di Kabupaten Lebak.

Menurut sintesis teori dalam pendahuluan, minat belajar adalah memiliki kecenderungan yang tetap untuk memperhatikan dan mengenang sesuatu secara 
terus menerus, memperoleh kebanggaan dan kepuasan terhadap hal yang diminati. Ketika ada minat dalam belajar maka siswa akan senantiasa aktif berpartisipasi dalam pembelajaran dan akan memberikan prestasi yang baik dalam pencapaian prestasi belajar dalam hal ini adalah kemampuan menulis deskripsi. Hal ini mengandung arti bahwa minat belajar siswa memberikan pengaruh yang signifikan terhadap peningkatan kemampuan menulis deskripsi siswa SMP Negeri di Kabupaten Lebak.

\section{SIMPULAN}

Berdasarkan dari hasil pengujian hipotesis penelitian dan analisis data diatas dapat disimpulkan bahwa terdapat pengaruh yang signifikan persepsi siswa atas gaya hidup digital dan minat belajar secara bersama-sama terhadap kemampuan menulis deskripsi siswa SMP Negeri di Kabupaten Lebak. Hal ini dibuktikan dengan perolehan nilai Sig. $0,000<0,05$ dan $F_{h}=13,868$., terdapat pengaruh yang signifikan persepsi siswa atas gaya hidup digital terhadap kemampuan menulis deskripsi siswa SMP Negeri di Kabupaten Lebak. Hal ini dibuktikan dengan perolehan nilai Sig. 0,006 $<0,05$ dan $t_{h}=2,798$, dan ttrdapat pengaruh yang signifikan minat belajar terhadap kemampuan menulis deskripsi siswa SMP Negeri di Kabupaten Lebak. Hal ini dibuktikan dengan perolehan nilai Sig. 0,000<0,05 dan $t_{h}=3,720$.

\section{DAFTAR PUSTAKA}

Adisaputro, G. (2014). Manajemen pemasaran (Analisis Untuk perancangon strategi pemasaran). Yogyakarta: UPP STIM YKPN.

BSNP. (2006). Standar isi dan standar isi untuk satuan pendidikan dasar dan menengah. Jakarta: kemendiknas

Rolnicki, T. E. (2008). Pengantar dasar jurnalisme. Jakarta: Prenada Media Grup.

Semi, M. A. (2007). Dasar-dasar keterampilan menulis. Bandung: Angkasa.

Slameto. (2018). Belajar dan faktor-faktor yang mempengaruhi. Jakarta: Rineka Cipta.

Soehardi, S. (2003). Perilaku organisasi. Yogyakarta: BPFE UST.

Sugihartono, F. K., Harahap, F., Setiawati, F. A., \& Nurhayati, S. R. (2007). Psikologi pendidikan. Yogyakarta: UNY Press.

Suhendar. (2002). MKDU Bahasa Indonesia pengajaran dan ujian keterampilan membaca \& keterampilan menulis. Bandung: Pionir Jaya.

Syah, M. (2003). Psikologi belajar. Jakarta: Raja Grafindo Persada. 